Joanna Filaber iD https://orcid.org/0000-0002-3731-2679

Wyższa Szkoła Bankowa we Wrocławiu

\title{
Odpowiedzialność pozaprawna organów gminy w sferze bezpieczeństwa publicznego
}

\author{
https://doi.org/10.25312/2391-5110.14/2019_02jf
}

\begin{abstract}
Streszczenie
Artykuł porusza tematykę odpowiedzialności organów gminy za niewykonanie bądź nienależyte wykonanie zadania publicznego, jakim jest zapewnienie bezpieczeństwa publicznego mieszkańcom podstawowej jednostki samorządu terytorialnego. Autorka rozpoczyna analizę od wyjaśnienia pojęcia bezpieczeństwa publicznego i tematyki odpowiedzialności wraz z jej klasyfikacją na odpowiedzialność prawną i pozaprawną. Centralna część rozważań koncentruje się na tematyce odpowiedzialności politycznej i etycznej organów gminy w zakresie bezpieczeństwa publicznego. Wnioski końcowe ukazują złożoność tematyki odpowiedzialności za bezpieczeństwo w gminie. Autorka podkreśla konieczność realizacji zadań publicznych w ramach decentralizacji władzy samorządowej na podstawie wartości „New public management” (efektywność, skuteczność i ekonomika), uzupełnionych o paradygmat etycznego zarządzania, który może pomóc administracji publicznej - zwłaszcza samorządowej - w odzyskaniu zaufania publicznego.
\end{abstract}

Słowa kluczowe: odpowiedzialność, gmina, bezpieczeństwo publiczne

\section{Summary}

\section{Municipal non-legal responsibility in the sphere of public security}

This article considers municipal responsibility for the non-performance or improper performance of tasks related to the security of the inhabitants of local government areas. The author analyses the concept of public security and the way in which responsibility 
for public security is legally classified. The article focuses on the notion of political and ethical responsibility of municipal bodies in terms of public security. The conclusion discusses the complexity of the issue. The author claims that the fulfilment of public tasks in the context of decentralisation of local government should be based on the "New public management" values (effectiveness, efficiency and economy) supplemented with the paradigm of ethical management that can help public administration, mainly local authorities, to gain public trust.

Keywords: responsibility, commune, public security

\section{Uwagi wstẹpne}

W Rzeczypospolitej Polskiej niewykonanie bądź nienależyte wykonanie przez organy gminy zadania publicznego, jakim jest zapewnienie bezpieczeństwa publicznego mieszkańcom wspólnoty samorządowej, w myśl art. 7 ust. 14 Ustawy z dnia 8 marca 1990 r. o samorządzie gminnym ${ }^{1}$, rodzi odpowiedzialność organów gminy. Przedmiotową odpowiedzialność regulują przede wszystkim przepisy prawa, ale bardzo ważne miejsce zajmują też czynniki pozaprawne, do których należą między innymi: normy etyczne i prawo moralne oraz polityka.

W demokratycznym państwie prawa zadania administracji publicznej, będące obowiązkami administracyjnymi, określane są w normach prawa powszechnie obowiązującego, dlatego też organy władzy publicznej nie mają swobody w decydowaniu o tym, co ma być ich zadaniami publicznymi. Swoboda administracji ma miejsce jedynie w zakresie wyboru sposobu realizacji zadań publicznych i to zawsze w granicach zakreślonych przez normy prawa. Tym samym organy gminy nie mają własnych wolności i praw, a jedynie kompetencje, które umożliwiają i zobowiązują do podejmowania działań dla dobra publicznego, dla dobra i na rzecz obywateli wspólnoty samorządowej - w tym do zapewnienia bezpieczeństwa publicznego na terenie gminy. Zważywszy na to, że realizowanie przez obywateli swoich praw i korzystanie z wolności powinno się dokonywać w warunkach pewności, stabilności i zaufania do organów władzy publicznej, problematyka odpowiedzialności administracji publicznej jest kluczowa w państwie prawa.

Ze względu na złożoność problematyki odpowiedzialności administracji publicznej jest to obszar badawczy, który, niestety, bardzo często jest pomijany w opracowaniach naukowych, a przecież odpowiedzialność organów gminy za działania bądź zaniechania w sferze bezpieczeństwa publicznego ma dla obywatela zasadnicze znaczenie.

Celem artykułu jest przedstawienie tematyki odpowiedzialności pozaprawnej, szczególnie politycznej i etycznej, organów gminy w ramach systemu odpowiedzialności w obszarze bezpieczeństwa publicznego w Rzeczypospolitej Polskiej. Dzięki wyjściu poza kanony regulacji prawnych autorka wskazuje na konieczność wprowadzenia nowego modelu w procedurę zarządzania w samorządzie gminnym, tj. od realizacji zadań w ramach decentralizacji władzy publicznej i założenia „New public management” po konieczność współistnienia paradygmatu etycznego zarządzania, co jedynie łącznie doprowadzi do - po pierwsze -

\footnotetext{
${ }^{1}$ Dz.U. z 2019 r., poz. 506 ze zm.
} 
odzyskania utraconego zaufania publicznego, a po drugie - budowania nowego zaufania na fundamentach inkluzji społeczeństwa obywatelskiego i organów władzy publicznej we wspólnocie samorządowej.

\section{Procesy definicyjne w problematyce odpowiedzialności za bezpieczeństwo publiczne, czyli o braku definicji legalnych w przepisach prawa RP - uwagi wybrane}

W Rzeczypospolitej Polskiej niewykonanie bądź nienależyte wykonanie zadania publicznego, jakim jest zapewnienie bezpieczeństwa publicznego w gminie, rodzi odpowiedzialność organów władzy publicznej. Odpowiedzialność tę regulują zarówno przepisy prawa, jak i czynniki pozaprawne. Należy wskazać, że już Konstytucja Rzeczypospolitej Polskiej z 4 kwietnia 1997 r. $^{2}$ w art. 77 ust. 1 przyznała każdemu prawo do wynagrodzenia szkody wyrządzonej przez niezgodne z prawem działanie organu władzy publicznej, w tym za niezapewnienie bezpieczeństwa publicznego w gminie. Ustawodawca stworzył zatem jedynie podstawy prawne dochodzenia do odpowiedzialności, ale na czym polega przedmiotowa odpowiedzialność za bezpieczeństwo, nie jest już prawnie uregulowane, tzn. ustawodawca nie stworzył definicji legalnej i nie dokonuje enumeratywnego wyliczenia przypadków braku zapewnienia bezpieczeństwa publicznego - jako braku działania lub zaniechania na poziomie gminy ani innej jednostki samorządu terytorialnego.

Analizując znaczenie terminologiczne pojęcia bezpieczeństwo publiczne, należy wskazać, że występuje ono zarówno w aktach normatywnych rangi ustawowej, jak i w aktach prawnych niższego rzędu. Dodatkowo zakres stosowania tego pojęcia przez ustawodawcę w przepisach prawnych różnej rangi stale się zwiększa z uwagi na wzrastającą w świecie prawną, a także społeczną i polityczną rolę bezpieczeństwa publicznego. Podkreślić jednak należy, że pojęcie bezpieczeństwo publiczne, które notabene oznacza najważniejsze zadanie państwa i jego najważniejszą funkcję, nie zostało dotychczas w sposób precyzyjny określone w przepisach prawa ${ }^{3}$.

Tym samym ustawodawca nie stworzył w żadnym akcie prawnym definicji legalnej tego terminu, mimo że posługuje się nim wielokrotnie w aktach prawnych, począwszy od regulacji w obszarze stanów nadzwyczajnych, sytuacji kryzysowej, po imprezy masowe, prawo budowlane, ochronę środowiska, transport i inne. Ponadto w piśmiennictwie prawniczym zagadnienie to bardzo często przedstawiane jest w sposób fragmentaryczny, odnoszący się tylko do szczególnych dziedzin prawa, czyli jako bezpieczeństwo rodzajowe, tj. w prawie wodnym, w prawie gospodarczym, w prawie transportowym i morskim, aż po bezpieczeństwo w prawie konstytucyjnym i prawie karnym włącznie. Brak definicji legalnej jest zatem uzupełniony jedynie określeniem ustawowych desygnatów pojęcia bezpieczeństwa ${ }^{4}$,

${ }^{2}$ Dz.U. z 1997 r. nr 78, poz. 483 ze zm.

3 J. Filaber, Pojęcie bezpieczeństwa publicznego w prawie administracyjnym (wybrane uwagi), „Wrocławskie Studia Erazmiańskie, Studia Erasmiana Wratislaviensia Acta Studentium”2009, s. 259-260, https://www.bibliotekacyfrowa.pl/dlibra/publication/27852/edition/34474/content [dostęp: 30.12.2019].

${ }^{4}$ Ustawodawca wskazuje desygnaty pojęcia bezpieczeństwa publicznego, które występują w obrocie prawnym nie jako abstrakcyjne pojęcie nauki prawa administracyjnego, lecz jako wartość konstytucyjna, 
a definicji i interpretacji nadal należy szukać w doktrynie i orzecznictwie sądowym, które w tym przypadku są pomocne w stosowaniu prawa wobec obywateli.

Odnosząc się zaś do znaczenia terminu odpowiedzialność, wskazać należy, że ustawodawca także nie tworzy definicji legalnej w przepisach prawa i w tym zakresie trzeba się posiłkować znaczeniem leksykalnym terminu, oznaczającym konieczność, obowiązek moralny lub prawny odpowiadania za swoje czyny i ponoszenia za nie konsekwencji, to znaczy: odpowiadanie przed kimś, wobec kogoś lub za cośs. Najpełniej działania definicyjne zamyka termin wskazany przez W. Langa, który pojęcie odpowiedzialności rozumie jako ponoszenie przez podmiot przewidzianych prawem ujemnych konsekwencji za zdarzenia i stany rzeczy podlegające ujemnej klasyfikacji normatywnej i przypisywane prawnie określonemu podmiotowi w danym porządku prawnym ${ }^{6}$.

\section{Odpowiedzialność prawna organów gminy w zakresie bezpieczeństwa publicznego}

Na podstawie dorobku wrocławskiej nauki prawa administracyjnego wyodrębnić należy dwa pola odpowiedzialności, tj. odpowiedzialność za działania legalne administracji i odpowiedzialność za działania nielegalne ${ }^{7}$. Za przyjętym nurtem badań w ramach odpowiedzialności prawnej organów gminy w zakresie bezpieczeństwa publicznego można wyodrębnić dwie postacie tej odpowiedzialności: odpowiedzialność za działania legalne i odpowiedzialność za działania nielegalne.

Odpowiedzialność za działania legalne organów gminy w sferze bezpieczeństwa publicznego obejmuje przede wszystkim odpowiedzialność majątkową za działanie podejmowane w ściśle określonych w powszechnie obowiązującym prawie przypadkach i to zawsze w interesie publicznym. W szczególności mowa tu o konstytucyjnej regulacji wyrównania strat majątkowych wynikających z ograniczeń w czasie stanów nadzwyczajnych wolności i praw obywateli. Do katalogu legalnych działań administracyjnych wywołujących straty i podlegających wyrównaniu zalicza się również zniszczenie, uszkodzenie, zużycie lub utratę mienia w ramach świadczeń nakazanych dla zwalczania klęsk żywiołowych, a ponadto utra-

dla ochrony której możliwe jest ograniczenie korzystania przez obywateli z wolności i praw; zadanie naczelnych, centralnych, terenowych organów administracji rządowej, organów jednostek samorządu terytorialnego oraz organów wyspecjalizowanych. Dodatkowo pojęcie bezpieczeństwo publiczne występuje jako zadanie podmiotów prywatnych, zadanie organizacji i instytucji społecznych oraz obywateli, a także jako przesłanka uzasadniająca cofnięcie określonych uprawnień.

${ }_{5}$ M. Szymczak (red.), Stownik języka polskiego, PWN, Warszawa 1979, s. 469. Ponadto w Stowniku poprawnej polszczyzny pod red. W. Doroszewskiego (PWN, Warszawa 1980, s. 442) termin odpowiedzialność rozumiany jest w następujących kontekstach: 'brać, wziąć coś na swoją odpowiedzialność', 'brać na siebie odpowiedzialność za coś', 'ponieść odpowiedzialność', 'obarczać kogoś odpowiedzialnością', 'odpowiedzialność za kogoś, za coś'. Natomiast zgodnie z Encyklopedia popularną PWN pod red. R. Marcinkowskiego (PWN, Warszawa 1990, s. 535) odpowiedzialność prawna to obowiązek ponoszenia przewidywanych przez przepisy prawne konsekwencji zachowania się własnego lub innych osób.

${ }^{6}$ W. Lang, Struktura odpowiedzialności prawnej. Studium analityczne z dziedziny teorii prawa, „Zeszyty Naukowe UMK” 1968, nr VIII, cyt. za Z. Radwański (red.), Prawo zobowiąań - część ogólna. System prawa cywilnego, t. III, cz. I, Ossolineum, Wrocław 1981, s. 166.

${ }^{7}$ A. Błaś, J. Boć, J. Jeżewski, Nauka administracji, Kolonia Limited, Wrocław 2013, s. 339 i nast. 
tę lub uszkodzenie oraz szkody wynikłe z używania przedmiotów świadczeń rzeczowych nałożonych na rzecz obrony. Wymienione przykłady wyrównania straty z tytułu legalnego działania organów administracji publicznej można analizować między innymi w aspekcie szkód poniesionych z powodu wydania lub wykonania niewadliwych decyzji administracyjnych na podstawie prawa wodnego oraz problematyki wywłaszczenia nieruchomości.

W ramach odpowiedzialności organów gminy za działania nielegalne w zakresie bezpieczeństwa publicznego wymienić należy: niewykonanie lub nienależyte wykonanie zadań przez organy stanowiące i wykonawcze podstawowej jednostki samorządu terytorialnego, które może być przesłanką odpowiedzialności cywilnoprawnej, zwanej też odpowiedzialnością majątkową bądź odszkodowawczą. Sytuacja ta będzie miała miejsce wówczas, gdy prawnie określone zadanie publiczne nie jest wykonywane przez zobowiązany prawnie organ gminy, skutkiem niewykonania tego obowiązku publicznego jest zaś szkoda w rozumienia prawa cywilnego. W ramach odpowiedzialności organów gminy za działania nielegalne mieści się także odpowiedzialność karna gminnych funkcjonariuszy administracji publicznej za przestępstwa związane z zapewnieniem bezpieczeństwa publicznego. Dodatkowo obok odpowiedzialności cywilnej, karnej trzeba wymienić również odpowiedzialność dyscyplinarną (służbową).

\section{Odpowiedzialność pozaprawna a odpowiedzialność prawna organów gminy w zakresie bezpieczeństwa publicznego}

W demokratycznym państwie prawa organy administracji publicznej zobowiązane są do wykonywania zadań publicznych na podstawie i w granicach prawa. Dodatkowo obowiązują kryteria pozaprawne, które w sposób bezpośredni określają przesłanki pozaprawnej, czyli politycznej i etycznej odpowiedzialności organów gminy.

Otwierając dalsze rozważania, należy wyjść od tezy, że odpowiedzialność ma głębokie znaczenie nie tylko w aspekcie prawnym, ale również $\mathrm{w}$ aspekcie pozaprawnym, między innymi moralnym. Sama zaś odpowiedzialność to nic innego jak przekonanie, że jest się rzeczywistym sprawcą aktu i jego skutków. Do tego, by poczucie odpowiedzialności się rozwinęło, człowiek musi mieć przekonanie, że w konkretnej sytuacji, w jakiej się znalazł, nie tylko wiedział, co należy zrobić, lecz rzeczywiście mógł to zrobić8

\section{Odpowiedzialność polityczna organów gminy w zakresie bezpieczeństwa publicznego}

Odpowiedzialność polityczna nie jest regulowana prawem powszechnie obowiązującym, a jedynie aktami wewnętrznymi w ramach ugrupowań politycznych. W doktrynie odpowiedzialność ta bywa definiowana jako odpowiedzialność o charakterze ogólnym - za

${ }^{8}$ J. Tischner, Wobec wartości, Wydawnictwo Polskiej Prowincji Dominikanów „W drodze”, Poznań 1992, s. 100. 
określony stan rzeczy ${ }^{9}$. Niektórzy autorzy odpowiedzialność polityczną określają również jako odpowiedzialność przed wyborcami ${ }^{10}$, co znajduje szczególne odzwierciedlenie w ordynacji wyborczej, która sprzyja poglądowi o upolitycznianiu samorządu, przez co i decyzje wyborców mają coraz bardziej polityczny charakter ${ }^{11}$.

Odpowiedzialność polityczna wiąże się z oceną podejmowanych przez organy gminy działań w sferze zapewnienia bezpieczeństwa publicznego na terenie swojego działania. Kryteria tej oceny nie prowadzą do badania legalności działania organów gminy, choć jest to najczęstsze kryterium analizy. W tym kontekście ważne są bowiem nie tylko takie czynniki jak dobra wola, zgodność z zasadami moralnymi czy z normami prawnymi w działalności organu gminy, ale też ogólny wynik gospodarczy i społeczny tej działalności. W efekcie kryteria odpowiedzialności sformułowane w prawie są jedynie kryteriami cząstkowymi i nie obejmują na przykład zwykłej nieudolności, bezczynności, głupoty, poddaństwa politycznego czy bezczelności w traktowaniu ludzi i państwa. Tym samym podkreślić należy znaczenie powyższych pozaprawnych ocen, które urastają do rangi jednej z podstawowych przesłanek aprobaty określonej działalności organów gminy o zasięgu lokalnym ${ }^{12}$, obok kryterium prawnego działania organów podstawowej jednostki samorządu terytorialnego.

W ramach odpowiedzialności politycznej można wyróżnić odpowiedzialność przed społeczeństwem lub jego mniejszymi grupami, w tym społecznościami lokalnymi, podmiotami nadrzędnymi, i wreszcie odpowiedzialność wewnątrzpartyjną. W ramach ocen społeczeństwo lokalne może przyjmować za podstawę skuteczność działań w sferze zapewnienia bezpieczeństwa publicznego obywatelom gminy bądź też wywiązywanie się z przedwyborczych obietnic, które mogłyby polegać na przykład na wzmocnieniu czy budowie wałów przeciwpowodziowych, zakupie nowego - lepszego sprzętu dla gminnych jednostek i formacji mundurowych czy zapewnieniu rozwoju określonej jednostce administracyjnej w kierunku wzmocnienia poziomu bezpieczeństwa. Należy jednakże pamiętać, że pomimo wyraźnych obietnic wyborczych dokonywanie przez obywateli gminy oceny działania organów samorządowych nie ma z reguły charakter merytorycznego, a subiektywny, który oparty jest na dodatkowych kryteriach, bardzo często znanych tylko osobie dokonującej oceny.

W przypadku negatywnej oceny działalności organów gminy, dokonanej przez społeczeństwo lokalne w zakresie między innymi braku wystarczającego poziomu bezpieczeństwa publicznego, mogą zostać podjęte dalsze decyzje w drodze czy to kolejnych wyborów

${ }^{9}$ H. Izdebski, M. Kulesza, Administracja publiczna. Zagadnienia ogólne, Liber, Warszawa 2004, s. 129.

${ }_{10}$ B. Kudrycka, Parę uwag na temat etycznego administrowania przez samorzad terytorialny w Polsce, [w:] Z. Niewiadomski (red.), Administracja publiczna u progu XXI wieku: prace dedykowane prof. zw. dr. hab. Janowi Szreniawskiemu z okazji Jubileuszu 45-lecia pracy naukowej, Wyższa Szkoła Administracji i Zarządzania, Przemyśl 2000, s. 328.

${ }_{11}$ R. Budzisz, dz. cyt., s. 253. Por. też: B. Kudrycka, Neutralność polityczna urzędników, Wydawnictwo Sejmowe, Warszawa 1988; J.S. Święcki, K. Święcka, Apolityczność urzędników administracji samorzqdowej na szczeblu gminy a wpływ partii politycznych na spoleczności lokalne, [w:] J. Łukasiewicz (red.), Nauka administracji wobec wyzwań współczesnego państwa prawa, Towarzystwo Naukowe Organizacji i Kierownictwa, Rzeszów-Cisna 2002, s. 519 i nast.

${ }_{12}$ J. Boć, Odpowiedzialność, [w:] A. Błaś, J. Boć, J. Jeżewski, Administracja publiczna, Kolonia Limited, Wrocław 2010, s. 345. 
samorządowych, czy też referendów gminnych i w efekcie odwołania organów gminy. W kontekście naruszenia przepisów prawa lub braku skuteczności w realizacji zadań publicznych może dojść do uruchomienia procedur nadzoru w trybie rozdziału 10 ustawy o samorządzie gminnym.

W zakresie odpowiedzialności za działanie niezgodne z wytyczoną linią polityczną sankcją może być odwołanie ze stanowiska, cofnięcie poparcia lub taż zainicjowanie działań mających na celu pozbawienie zajmowanego stanowiska lub też zablokowanie negatywnie ocenionych prac. Przykładowo: rada gminy może zainicjować referendum w sprawie odwołania organu wykonawczego lub próbować w tym trybie zablokować jego działania w zakresie niezapewnienia bezpieczeństwa publicznego, które są później weryfikowane przez samych uczestników referendum, czyli mieszkańców podstawowej jednostki samorządu terytorialnego ${ }^{13}$.

Omawiając problematykę odpowiedzialności politycznej organów gminy w zakresie bezpieczeństwa publicznego, pamiętać należy, że dotyczy ona zawsze odpowiedzialności przed społecznością lokalną, której bardzo często brakuje konsekwencji. Do tego dochodzi jeszcze brak ostrości oceny działań podejmowanych przez wójtów, burmistrzów i prezydentów miast w zakresie zapewnienia bezpieczeństwa publicznego na terenie podstawowej jednostki samorządu terytorialnego. Oczywiście sytuację tę utrudnia przerzucanie odpowiedzialności na podmioty zewnętrzne, a tym samym unikanie negatywnych ocen i skutków podejmowanych przez organy gminy niekorzystnych działań na terenie gminy. Najbardziej jest to widoczne w zakresie zaniechania działań zmierzających do rozwoju i poprawiania jakości życia mieszkańców, którzy często nie wiedzą o możliwościach wzmocnienia bezpieczeństwa publicznego w gminie oraz działaniach niweczonych przez nieskuteczną, nieekonomiczną i nieprofesjonalną administrację samorządową.

\section{Odpowiedzialność etyczna organów gminy w zakresie bezpieczeństwa publicznego}

Odpowiedzialność etyczna jest rodzajem odpowiedzialności zawieszonej pomiędzy wieloma sferami działalności administracji i mimo że nie jest prawnie uregulowana - gdyż na straży samych norm etycznych stoi wyłącznie sumienie weryfikujące ludzkie działanie ${ }^{14}$ - to jest fundamentem porządku prawnego w każdym państwie demokratycznym. Naruszenie norm etycznych niesie bowiem ze sobą odpowiedzialność moralną, a w przypadku naruszenia norm moralnych ujętych w normach prawnych działanie bądź też zaniechanie rodzi obok samej odpowiedzialności moralnej (odpowiedzialności w sumieniu) również odpowiedzialność prawną ${ }^{15}$.

\footnotetext{
13 R. Budzisz, dz. cyt., s. 255.

14 I. Kant, Uzasadnienie metafizyki moralności, PWN, Warszawa 1971, s. 50.

15 A. Błaś, J. Boć, J. Jeżewski, Administracja ..., dz. cyt., s. 279-280.
} 
Etykę definiuje się jako zbiór zasad i norm moralnych przyjętych przez określoną zbiorowość (społeczeństwo, grupę zawodową, społeczność lokalną) w określonym czasie ${ }^{16}$. Dla sprecyzowania zbioru tych norm przedstawiciele doktryny prawa administracyjnego używają określenia prawo moralne, odróżniając je od prawa stanowionego powszechnie obowiązującego. Podkreśla się w ten sposób więzy nierozerwalnie łączące obydwie grupy norm i wzajemne ich zależności ${ }^{17}$. Etyka w administracji publicznej zabezpiecza interes publiczny, a ponadto jest podstawą dobrych rządów i kształtuje pozytywne wartości w życiu publicznym. Dodatkowo etyka legitymizuje działania, przeciwdziała i zapobiega patologiom (w tym zjawiskom korupcyjnym), a także ułatwia podejmowanie trudnych decyzji administracyjnych przez urzędników ${ }^{18}$.

Tematyka odpowiedzialności etycznej jest przedmiotem często poruszanych zagadnień podnoszenia standardów etycznych w administracji przez bardziej sformalizowane ustalanie czy też nawet narzucanie odpowiednich norm etycznych. Działania te materializują się często w postaci kodeksów etycznych przyjmowanych przez urzędy samorządowe i państwowe.

Na szczególną uwagę zasługuje projekt rozporządzenia Prezesa Rady Ministrów w sprawie ustanowienia Kodeksu Etyki Pracownika Samorządowego ${ }^{19}$, który - mimo że nie został przyjęty - jednoznacznie wskazywał, w jakim kierunku powinny zmierzać działania skierowane na sformalizowanie zasad etycznego postępowania urzędników samorządowych ${ }^{20}$.

${ }^{16}$ M. Szymczak, dz. cyt., s. 559; por. też E. Sobol (red.), Słownik wyrazów obcych, Wydawnictwo Naukowe PWN, Warszawa 2000, s. 312.

${ }_{17}$ Zob. szerzej A. Błaś, Normy etyczne pracownika administracji publicznej w państwie prawa, [w:] A. Błaś, J. Boć, J. Jeżewski, Administracja publiczna, Kolonia Limited, Wrocław 2010, s. 277 i nast. Między powinnością moralną a prawami człowieka istnieje pewna logiczna korelacja. Tam, gdzie występuje prawo człowieka, które należy respektować, na ogół istnieje też moralna powinność respektowania tego prawa. Rozpatrując prawa i powinności, trzeba odróżnić ogólne, dotyczące wszystkich ludzi od przypadków szczególnych, charakterystycznych dla konkretnych ról społecznych. Chodzi tu o powinności i prawa właściwe dla roli między innymi: urzędnika, radnego, posła, senatora, kierownika, dyrektora, menedżera. Te specyficzne obowiązki i uprawnienia pojawiają się wraz z podjęciem pracy. Są one pewnymi zobowiązaniami i żądaniami nałożonymi na te prawa i powinności, które mają wszyscy i - co najistotniejsze - nie zastępują ich ani też ich nie anulują. Stanowią do nich dodatek i nakładają dodatkową odpowiedzialność, czerpiąc legitymizację ze zgodności z fundamentalnymi zasadami, cyt. za A. Strzelecki, Aspekty normatywne wzorca osobowego urzędnika publicznego, [w:] D. Bąk (red.), Etos urzędnika, Wydawnictwa Akademickie i Profesjonalne: Wyższa Szkoła Przedsiębiorczości i Zarządzania im. Leona Koźmińskiego, Warszawa 2007, s. 95.

${ }_{18}$ B. Kudrycka, Dylematy etyczne pracowników administracji, Wydawnictwo Temida 2, Białystok 1995, s. 142-148. Zainteresowanie sprawami etyki urzędniczej w literaturze polskiej było już przedmiotem opracowań monograficznych, począwszy od lat siedemdziesiątych. W szczególności wskazać należy monografię S. Kowalewskiego, Etyka administracji, Instytut Wydawniczy Związków Zawodowych, Warszawa 1975.

${ }_{19}$ Kodeks dostępny na stronie Kancelarii Prezesa Rady Ministrów (www.kprm.gov.pl).

${ }^{20}$ Zgodnie z art. 1 projektu Kodeksu Etyki Pracownika Samorządowego: „Kodeks wyznacza zasady (standardy) postępowania pracowników samorządowych w związku z wykonywaniem przez nich zadań publicznych (pełnienia służby publicznej) oraz niezwiązanych bezpośrednio z ich wykonywaniem, a mających wpływ na zaufanie obywateli do działania instytucji publicznych. Normy niniejszego Kodeksu naruszają pracownicy samorządowi, którzy wskutek postępowania, zarówno w miejscu pracy, jak i poza nim, ryzykują utratę zaufania niezbędnego przy wykonywaniu zadań publicznych. Projekt określa także sposób wykonywania zadań przez pracowników samorządowych. Zgodnie z nim pracownicy samorządowi: działają bezstronnie i bezinteresownie; nie uczestniczą w podejmowaniu decyzji, narad, opiniowaniu lub głosowaniu w sprawach, w których mają bezpośredni lub pośredni interes osobisty; nie wykorzystują i nie pozwalają na wykorzystanie powierzonych im zasobów, kadr i mienia publicznego w celach prywat- 
Biorąc pod uwagę regulacje prawne zawarte w przedmiotowym projekcie, wskazać należy, że pracownicy samorządowi powinni traktować pracę jako służbę publiczną, a na zajmowanych stanowiskach służyć państwu i wspólnotom samorządowym, ponadto zobligowani są do przestrzegania porządku prawnego i wykonywania powierzonych zadań publicznych. W tym miejscu postuluję obowiązkowość wprowadzenia przez wójtów (burmistrzów, prezydentów miast) kodeksów etycznych pracowników urzędów gminy w formie zarządzenia, na podstawie art. 30 ust. 1 i 3 ustawy o samorządzie gminnym oraz art. 68 i art. 69 ust. 1 pkt 3 Ustawy z dnia 27 sierpnia 2009 r. o finansach publicznych (Dz.U. z 2019 r., poz. 869 ze zm.).

Dodatkowo zgodnie z ogólnie przyjętymi zasadami urzędnicy administracji publicznej powinni traktować urząd publiczny jako służbę w interesie publicznym (urząd zaufania publicznego), a swoim działaniem pogłębiać zaufanie do urzędu publicznego. Ponadto pracownicy samorządowi, ponoszący odpowiedzialność przed społeczeństwem, zobowiązani są rozstrzygać sprawy niezależnie i obiektywnie, uwzględniając jednocześnie demokratyczne przywództwo $^{21}$. Jednakże aby powyższymi cechami charakteryzowali się urzędnicy samorządowi, niezbędne jest wprowadzenie, utrzymanie i weryfikowanie wysokiego poziomu odpowiedzialności i profesjonalizmu ${ }^{22}$ wewnątrz samorządu terytorialnego.

Wysokie standardy etycznego postępowania będą coraz bardziej powszechne, o ile nastąpi konsekwentne wdrażanie infrastruktury etycznej do organizacji i metod administrowania sprawami lokalnymi. Potrzebne jest do tego wprowadzenie następujących rozwiązań jako założeń wyjściowych ${ }^{23}$ :

1) jawności i transparentności działań, dokumentów i posiedzeń organów samorządowych,

2) zapewnienie mechanizmów wewnętrznego audytu, które polegają na stałej analizie mechanizmów, struktur i procedur według kryteriów rzetelności, racjonalności i efektywności gospodarowania środkami publicznymi,

3) upowszechnianie standardów etycznych przez kodeksy etyki radnych i urzędników, 4) bezwzględne kierowanie funkcjonariusza publicznego do odpowiedzialności karnej, dyscyplinarnej, porządkowej i politycznej za naruszenie prawa i etyki.

W samorządzie lokalnym ogromne znaczenie ma odpowiedzialność urzędników nie tylko przed prawem, ale również przed wspólnotą lokalną. Wrażliwość na kwestie odpowiedzialności etycznej monitorują kodeksy etyki ustalające zasady pożądanego postępowania

nych; nie podejmują prac ani zajęć kolidujących z pełnionymi obowiązkami służbowymi; nie podejmują arbitralnych decyzji, które mogą mieć negatywny wpływ na sytuację obywateli oraz powstrzymują się od promowania jakichkolwiek grup interesów; pełniąc obowiązki, kierują się interesem wspólnoty samorządowej i nie czerpią dodatkowych korzyści materialnych czy osobistych (ani w trakcie zatrudnienia, ani po jego ustaniu) z tytułu sprawowania urzędu, nie działają też w prywatnym interesie osób lub grup osób”.

${ }^{21}$ A. Strzelecki, Aspekty normatywne..., dz. cyt., s. 99. Zob. A. Potoczek, Model współczesnego urzędnika wadministracji publicznej, [w:] B. Sprengel, A. Strzelecki (red.), Urzędnik wadministracji publicznej, Wyższa Szkoła Humanistyczno-Ekonomiczna, Włocławek 2005, s. 42 i nast.

22 Szerzej na temat profesjonalizmu w administracji publicznej zob. H. Kisilowska, Pojęcie profesjonalizmu we współczesnej administracji, [w:] A. Dębicka, M. Dmochowski, B. Kudrycka (red.), Profesjonalizm w administracji publicznej, Stowarzyszenie Edukacji Administracji Publicznej, Białystok 2004, s. 111.

${ }^{23}$ B. Kudrycka, Nowe wyzwania i trendy w reformowaniu sytuacji urzędników administracji publicznej, [w:] tejże (red.), Rozwój kadr administracji publicznej, Wyższa Szkoła Administracji Publicznej „Libra”, Białystok 2001, s. 39-40. 
w działaniach publicznych. Jednakże formułowanie zasad etyki ma sens tylko wówczas, gdy związane jest z konsekwentnym stosowaniem odpowiedzialności za ich naruszenie. Praktyczne egzekwowanie tych zasad jest kryterium weryfikacyjnym, wykazującym, czy przedsięwzięcia związane z etycznym, odpowiedzialnym administrowaniem są prawdziwe, czy tylko pozorne. Dopiero wtedy, gdy zasady etyczne są egzekwowane, pełnią funkcję dyscyplinującą i kontrolną, a także stymulującą, prewencyjną i ochronną. W przeciwnym razie jedynie pogłębiają kryzys zaufania do organów publicznych ${ }^{24}$.

Zasady etyczne są konieczne, ale same nie są skuteczne w zmniejszaniu działań niepożądanych, nieetycznych. Takimi mogą stawać się wówczas, gdy będą powiązane z pozostałymi przedsięwzięciami kształtującymi infrastrukturę etyczną, takimi jak jawność i transparentność działań, wewnętrzny audyt i szkolenia kształtujące wysoką wrażliwość etyczną oraz wskazujące na ekonomiczne, socjologiczne i prawne skutki działań nieetycznych ${ }^{25}$.

Wysokie standardy etycznego administrowania w samorządzie lokalnym pozwalają na osiągnięcie bardzo ważnych celów, między innymi: poprawy jakości administrowania usługami publicznymi ${ }^{26}$, skuteczniejszej ochrony interesu publicznego i interesu zbiorowości lokalnej przed nadużyciami ${ }^{27}$, a następnie odbudowy zaufania społecznego do organów samorządu terytorialnego, aby udowodnić zdolność do odpowiedniego do potrzeb, skutecznego i efektywnego administrowania sprawami publicznymi ${ }^{28}$.

Nie można uznać problematyki odpowiedzialności etycznej organów gminy w sferze bezpieczeństwa publicznego za w pełni zaprezentowaną bez ukazania i omówienia procesów, które występowały i występują w samej administracji publicznej. Jednym z nich jest proces decentralizacji władzy publicznej, który ujawnia brak zależności administracji samorządowej od administracji rządowej, a także potrzeby nadzoru nad wykonywaniem zadań publicznych, szczególnie w obszarze kontroli dysponowania środkami publicznymi i dokonywania wydatków publicznych w sferze bezpieczeństwa publicznego. Podstawowym założeniem musi być więc konieczność poprawy jakości zarządzania na skutek wzrastających potrzeb obywateli wobec usług publicznych ${ }^{29}$. Niezbędne jest zatem przejście od weberowskiego paradygmatu biurokracji ${ }^{30}$ do paradygmatu zarządzania publicznego, opartego na podejściu

24 Tamże, s. 40 .

25 Tamże, s. 40.

26 Poprawę jakości administrowania uzyskamy, jeśli rozwój usług publicznych odpowiadać będzie potrzebom mieszkańców, potrzebom wspólnoty lokalnej, jeśli nastąpi stałe ulepszenie organizacji pracy, struktur i procedur oraz elastyczne dostosowanie ich do zmiennych warunków i wyzwań, jeśli zasady ekonomiki, efektywności i skuteczności działań zostaną wdrożone jako kryteria realizacji zadań, a działania polityków i urzędników oceniane będą obiektywnie na podstawie rezultatów ich pracy.

27 Skuteczna ochrona interesu zbiorowości lokalnej nastąpi, jeśli do systemu organizacyjno-funkcjonalnego samorządu terytorialnego wdrożone zostaną elementy infrastruktury etycznej, takie jak jawność i transparentność działań, kodeksy etyki, wewnętrzna kontrola; nastąpi wyraźny rozdział ról, zadań i odpowiedzialności między stanowiskami politycznymi i urzędniczymi; każdy przypadek naruszenia prawa przez funkcjonariusza publicznego będzie sankcjonowany, a przepisy prawa nie będą tak interpretowane, by chronić interesy prywatne kolegów i przyjaciół, a nie interes publiczny; jednostki samorządowe włączą się konsekwentnie do działań antykorupcyjnych, wykorzystując w tym zakresie wiedzę i informacje płynące zarówno od mieszkańców, jak i bezpośrednio od urzędników.

28 Tamże, s. 41-42.

29 B. Kudrycka, Nowe wyzwania ..., dz. cyt., s. 26-27.

30 Paradygmat biurokracji weberowskiej oparty jest na anonimowości, neutralnym i profesjonalnym stosowaniu prawa oraz lojalnym realizowaniu polityki określonej przez każdą kolejną władzę wykonawczą. 
menedżerskim, wzroście wydajności i ograniczeniu kosztów działania administracji. Podejście to odnosi się przede wszystkim do sfery usług publicznych i polega na zastosowaniu metod i technik zarządzania przedsiębiorstwem.

Czy kluczowe wartości „New public management” - efektywność, skuteczność i ekonomika - są wystarczające dla ochrony bezpieczeństwa publicznego, a także szerzej dla ochrony dobra publicznego i interesu ogólnego mieszkańców wspólnoty samorządowej? Paradygmat ten ujawnia swoje ograniczenia i staje się przedmiotem coraz szerszej krytyki. Zarzuca mu się nieprzydatność tak w skali całego państwa, jak i dla rozwoju społeczności lokalnych. W tej sytuacji dominujący obecnie paradygmat nowego zarządzania publicznego jest uzupełniany nowym paradygmatem zarządzania etycznego, opierającym się na myśleniu kategoriami dobra społecznego.

Paradygmat etycznego zarządzania ${ }^{31}$ przyjmuje się coraz szerzej jako kierunek, który może pomóc administracji publicznej - zwłaszcza samorządowej - w odzyskaniu zaufania publicznego i rozwiązywaniu problemów, których samą technologią zarządzania nie można rozwiązać. Model ten stawiał nowe wymogi wobec urzędników, szczególnie tych na kierowniczych stanowiskach, a w odniesieniu do podstawowej jednostki samorządu terytorialnego - zwłaszcza wobec wójtów (burmistrzów, prezydentów miast), bo to właśnie na nich skupia się największa odpowiedzialność za zapewnienie bezpieczeństwa na terenie gminy.

Co zaś się tyczy podejmowania krytycznych decyzji, wyznaczania i wyboru drogi na przyszłość w zakresie zwiększenia bezpieczeństwa obywateli podstawowej jednostki samorządu terytorialnego, to organy gminy powinny kierować się kategoriami dobra społecznego na podstawie wartości etycznych akceptujących i tolerujących różnice poglądowe, a jednocześnie pozwalać na balansowanie konfliktów indywidualnych i społecznych ${ }^{32} \mathrm{w}$ celu zwiększenia bezpieczeństwa publicznego.

Przy wykonywaniu obowiązków prawnych organy gminy powinny obowiązywać normy etycznego działania. Radni, wójtowie, burmistrzowie, prezydenci miast ze względu na to, że są osobami zaufania publicznego, którym społeczność lokalna powierzyła swoje sprawy do administrowania, powinni być poddani nawet ostrzejszym rygorom etycznego postępowania niż inni urzędnicy i pracownicy samorządowi ${ }^{33}$. Niestety, w przypadku osób uzyskujących mandat w drodze wyborów powszechnych, w tym organu wykonawczego gminy, w zakresie odpowiedzialności etycznej nie występują odrębne rodzaje sankcji za naruszenie norm etycznych. Obok odpowiedzialności w sumieniu mogą one przybrać w przypadku uregulowania ich w prawie powszechnie obowiązującym - charakter sankcji karnej, zwłaszcza gdy nieetyczny czyn wypełni znamiona przestępstwa lub też ma charakter sankcji politycznych i skutkuje utratą zaufania społecznego albo ugrupowania politycznego popierającego osobę pełniącą funkcję wójta, burmistrza i prezydenta miasta ${ }^{34}$.

${ }^{31}$ M. Dębicki, Urzędnik XXI wieku, [w:] B. Kudrycka (red.), Rozwój kadr administracji publicznej, Wyższa Szkoła Administracji Publicznej „Libra”, Białystok 2001, s. 9-10.

${ }^{32}$ Tamże, s. 13-14.

33 B. Kudrycka, Parę uwag..., dz. cyt., s. 329.

${ }^{34}$ R. Budzisz, dz. cyt., s. 258. 


\section{Uwagi końcowe}

1. Odpowiedzialność, którą ponoszą organy gminy, stanowi ważny element demokratycznego państwa prawa, zapewniający bezpieczeństwo jego mieszkańcom. Jasność i precyzyjność przepisów w tym zakresie daje gwarancję należytego wypełniania zadań publicznych przez organy administracji. Im więcej instrumentów prawnych oraz pozaprawnych zwiększających odpowiedzialność organów gminy - kolegialnego organu stanowiącego i jednoosobowego organu wykonawczego, tym większa pewność, że nie naruszą one przepisów prawa w przyszłości.

2. Odpowiedzialność organów gminy w sferze bezpieczeństwa publicznego nie zależy wyłącznie od działań uregulowanych wyczerpująco normami prawnymi. Wymienić należy również inne czynniki nieznajdujące wyrazu w prawie, wyrażające się nie tylko w działaniach, czyli w aktach i czynnościach prawnie określonych, ale także w moralności, etyce, programie politycznym. Samo naruszenie norm etycznych niesie ze sobą odpowiedzialność moralną, a w przypadku naruszenia norm moralnych ujętych w normach prawnych działanie bądź też zaniechanie jest podstawą odpowiedzialności zarówno moralnej, jak i prawnej.

3. Obok norm etycznych, prawa moralnego, postulatów i obietnic politycznych to przede wszystkim powszechnie obowiązujące prawo wpływa na odpowiedzialność organów gminy i tym samym na jakość działania organów gminy w sytuacjach „,normalnych”, a także w czasach sytuacji kryzysowych, zagrożenia życia, zdrowia obywateli oraz w czasie wprowadzenia jednego ze stanów nadzwyczajnych: stanu klęski żywiołowej, stanu wyjątkowego, stanu wojennego. Dla obywatela demokratycznego państwa prawa niezbędne jest z jednej strony dobre prawo w zakresie poprawności legislacyjnej, a z drugiej prawo gwarantujące pewność sytuacji obywatela w realizacji praw i korzystania z wolności. Stabilność i zaufanie do organów władzy publicznej powinno być zapewnione nawet w czasie stanów nadzwyczajnych i innych sytuacji kryzysowych zagrażających życiu, zdrowiu i mieniu obywateli. W sytuacji wprowadzenia w czasie stanów nadzwyczajnych ograniczenia wolności i praw obywatele muszą mieć zagwarantowane konstytucyjne prawo wyrównania strat majątkowych wynikających z wprowadzonych ograniczeń.

4. Zakres odpowiedzialności organów gminy jest szeroki i zobowiązuje wójtów (burmistrzów, prezydentów miast) do szczególnej staranności w zakresie wykonywania swoich obowiązków publicznych, związanych zwłaszcza z zapewnieniem bezpieczeństwa publicznego mieszkańcom podstawowej jednostki samorządu terytorialnego. Staranność ta obejmuje także nadzór nad działaniami podjętymi przez pracowników podległych organowi wykonawczemu - pracowników Gminnego Centrum Zarządzania Kryzysowego i innych pracowników komórek urzędów gminy (miasta) właściwych w sprawach bezpieczeństwa publicznego, zarządzania kryzysowego i obrony cywilnej, którzy w imieniu wójta (burmistrza, prezydenta miasta) mogą dokonywać różnych działań w sferze bezpieczeństwa publicznego, narażających gminę na odpowiedzialność, szczególnie odszkodowawczą. W wyniku zaniedbań znaczne sumy środków finansowych z tytułu odszkodowania będą obciążać gminę jako osobę prawną działającą przez swoje organy ${ }^{35}$.

\footnotetext{
${ }^{35}$ J. Filaber, Ochrona bezpieczeństwa publicznego w gminie, Difin, Warszawa 2016, s. 186 i nast.
} 
5. Ochrona obywateli przed skutkami bezprawnych działań władzy publicznej w sferze niezapewnienia lub nienależytego zapewnienia bezpieczeństwa publicznego na terenie podstawowej jednostki samorządu terytorialnego należy do niezwykle ważnych i aktualnych problemów z dziedziny prawa cywilnego, które wiąże się jednocześnie z prawem administracyjnym i prawem konstytucyjnym. W istocie chodzi tu bowiem o gwarancję praw człowieka i obywatela oraz realizację zasady demokratycznego państwa prawa. Regulacja odpowiedzialności władzy publicznej stanowi wyznacznik praworządności danego państwa. Zapewnia ochronę przed bezprawnym zachowaniem funkcjonariuszy publicznych i jest prawem każdego człowieka, niezależnie od faktu posiadania obywatelstwa. Efektywność w realizacji zadań publicznych na terenie gminy będzie większa, gdy poza normami prawnymi w procedurze zarządzania zostaną wprowadzone normy moralne - etyczne, chociażby w postaci kodeksów etycznych urzędów gminy, a postulaty polityczne poza obietnicami wyborczymi będą obiektywnie weryfikowane przez samych wyborców.

\section{Bibliografia}

Błaś A., Boć J., Jeżewski J., Nauka administracji, Kolonia Limited, Wrocław 2013.

Błaś A., Normy etyczne pracownika administracji publicznej w państwie prawa, [w:] A. Błaś, J. Boć, J. Jeżewski, Administracja publiczna, Kolonia Limited, Wrocław 2010.

Boć J., Odpowiedzialność, [w:] A. Błaś, J. Boć, J. Jeżewski, Administracja publiczna, Kolonia Limited, Wrocław 2010.

Budzisz R., Doskonalenie modelu organu wykonawczego gminy w prawie polskim, Wydawnictwo Sejmowe, Warszawa 2010.

Dębicki M., Urzędnik XXI wieku, [w:] B. Kudrycka (red.), Rozwój kadr administracji publicznej, Wyższa Szkoła Administracji Publicznej „Libra”, Białystok 2001.

Doroszewski W. (red.), Słownik poprawnej polszczyzny PWN, PWN, Warszawa 1980.

Filaber J., Ochrona bezpieczeństwa publicznego w gminie, Difin, Warszawa 2016.

Filaber J., Pojęcie bezpieczeństwa publicznego w prawie administracyjnym (wybrane uwagi), „Wrocławskie Studia Erazmiańskie, Studia Erasmiana Wratislaviensia Acta Studentium”, Wrocław 2009, https://www.bibliotekacyfrowa.pl/dlibra/publication/27852/edition/34474/content [dostęp: 30.12.2019].

Izdebski H., Kulesza M., Administracja publiczna. Zagadnienia ogólne, Liber, Warszawa 2004.

Kant I., Uzasadnienie metafizyki moralności, PWN, Warszawa 1971.

Kisilowska H., Pojęcie profesjonalizmu we współczesnej administracji, [w:] A. Dębicka, M. Dmochowski, B. Kudrycka (red.), Profesjonalizm w administracji publicznej, Stowarzyszenie Edukacji Administracji Publicznej, Białystok 2004.

Kowalewski S., Etyka administracji, Instytut Wydawniczy Związków Zawodowych, Warszawa 1975.

Kudrycka B., Dylematy etyczne pracowników administracji, Wydawnictwo Temida 2, Białystok 1995. 
Kudrycka B., Neutralność polityczna urzędników, Wydawnictwo Sejmowe, Warszawa 1988.

Kudrycka B., Nowe wyzwania i trendy $w$ reformowaniu sytuacji urzędników administracji publicznej, [w:] tejże (red.), Rozwój kadr administracji publicznej, Wyższa Szkoła Administracji Publicznej „Libra”, Białystok 2001.

Kudrycka B., Pare uwag na temat etycznego administrowania przez samorzad terytorialny w Polsce, [w:] Z. Niewiadomski (red.), Administracja publiczna u progu XXI wieku: prace dedykowane prof. zw. dr. hab. Janowi Szreniawskiemu z okazji Jubileuszu 45-lecia pracy naukowej, Wyższa Szkoła Administracji i Zarządzania, Przemyśl 2000.

Lang W., Struktura odpowiedzialności prawnej. Studium analityczne z dziedziny teorii prawa, „Zeszyty Naukowe UMK” 1968, nr VIII.

Marcinkowski R. (red.), Encyklopedia popularna PWN, PWN, Warszawa 1990.

Potoczek A., Model współczesnego urzędnika w administracji publicznej, [w:] B. Sprengel, A. Strzelecki (red.), Urzędnik w administracji publicznej, Wyższa Szkoła Humanistyczno-Ekonomiczna, Włocławek 2005.

Radwański Z. (red.), Prawo zobowiązań - część ogólna. System prawa cywilnego, t. III, cz. I, Ossolineum, Wrocław 1981.

Sobol E. (red.), Słownik wyrazów obcych, Wydawnictwo Naukowe PWN, Warszawa 2000.

Strzelecki A., Aspekty normatywne wzorca osobowego urzędnika publicznego, [w:] D. Bąk (red.), Etos urzędnika, Wydawnictwa Akademickie i Profesjonalne: Wyższa Szkoła Przedsiębiorczości i Zarządzania im. Leona Koźmińskiego, Warszawa 2007.

Szymczak M. (red.), Słownik języka polskiego, PWN, Warszawa 1979.

Święcki J.S., Święcka K., Apolityczność urzędników administracji samorządowej na szczeblu gminy a wplyw partii politycznych na społeczności lokalne, [w:] J. Łukasiewicz (red.), Nauka administracji wobec wyzwań współczesnego państwa prawa, Towarzystwo Naukowe Organizacji i Kierownictwa, Rzeszów-Cisna 2002.

Tischner J., Wobec wartości, Wydawnictwo Polskiej Prowincji Dominikanów „W drodze”, Poznań 1992.

\section{Akty prawne}

Konstytucja Rzeczypospolitej Polskiej z dnia 4 kwietnia 1997 r., Dz.U. z 1997 r. nr 78, poz. 483 ze zm.

Ustawa z dnia 8 marca 1990 r. o samorządzie gminnym, Dz.U. z 2019 r., poz. 506 ze zm.

Ustawa z dnia 27 sierpnia 2009 r. o finansach publicznych, Dz.U. z 2019 r., poz. 869 ze zm. 